\title{
Cephalometric analysis for the diagnosis of sleep apnea: A comparative study between reference values and measure- ments obtained for Brazilian subjects
}

\author{
Patrícia Superbi Lemos Maschtakow¹, Jefferson Luis Oshiro Tanaka², João Carlos da Rocha³, Lílian Chrystiane Giannasi, \\ Mari Eli Leonelli de Moraes ${ }^{5}$, Carolina Bacci Costa ${ }^{6}$, Julio Cezar de Melo Castilho7, Luiz Cesar de Moraes ${ }^{8}$
}

Objective: To verify if the reference values of Sleep Apnea cephalometric analysis of North American individuals are similar to the ones of Brazilian individuals presenting no craniofacial anomalies. The study also aimed to identify craniofacial alterations in Obstructive Sleep Apnea-Hypopnea Syndrome (OSAHS) patients in relation to individuals without clinical characteristics of the disease through this cephalometric analysis. Method: It were used 55 lateral cephalograms consisting of 29 for the control group of adult individuals without clinical characteristics of OSAHS and 26 apneic adults. All radiographs were submitted to Sleep Apnea cephalometric analysis through Radiocef Studio 2.0. The standard values of this analysis were compared, by means of $z$ test, to the ones obtained from the control group and these were compared to values from apneic group through Student's $t$ test. Results: There were no significant differences between values obtained from control group and standard values. On the group of OSAHS patients it was observed a decrease on the dimensions of upper airways and an increase on the soft palate length. Conclusions: The standard values of Sleep Apnea analysis can be used as reference in Brazilian individuals. Besides, through lateral cephalograms it was possible to identify craniofacial alterations in OSAHS patients.

Keywords: Obstructive sleep apnea. Comparative study. Cephalometry

Objetivo: verificar se os valores de referência da análise cefalométrica para apneia do sono, referentes a indivíduos norte-americanos, são semelhantes aos de indivíduos brasileiros não portadores de anomalias craniofaciais. Identificar, também por meio dessa análise cefalométrica, alterações craniofaciais em indivíduos portadores de síndrome da apneia obstrutiva do sono (SAOS) em relação a indivíduos sem características clínicas da doença. Métodos: foram utilizadas 55 radiografias cefalométricas laterais advindas de arquivos, sendo 29 radiografias para o grupo controle, sendo composto de indivíduos adultos sem características clínicas de SAOS, e 26 de indivíduos adultos apneicos. Todas as radiografias foram submetidas à análise cefalométrica para apneia do sono por meio do software Radiocef Studio 2.0. Por meio do teste $z$, valores-padrão dessa análise foram comparados aos valores obtidos do grupo controle, e esses, por sua vez, foram comparados aos valores do grupo de apneicos por meio do teste $t$ de Student. Resultados: não houve diferenças significativas entre os valores obtidos do grupo controle e os valores-padrão. No grupo de indivíduos portadores de SAOS, observou-se diminuição nas dimensões das vias aéreas superiores e aumento do comprimento do palato mole. Conclusões: os valores-padrão da análise de apneia do sono podem ser utilizados como referência em indivíduos brasileiros. Além disso, por meio da radiografia cefalométrica lateral foi possível identificar alterações craniofaciais em indivíduos portadores de SAOS.

Palavras-chave: Apneia do sono tipo obstrutiva. Estudo comparativo. Circunferência craniana.

${ }^{1}$ Doctorate Student of the Program of Oral Biopathology at FOSJC-UNESP.

${ }^{2}$ Professor of the Specialization Course in Orthodontics APCD.

${ }^{3}$ Assistant Professor of Pediatric Dentistry at FOSJC-UNESP

${ }^{4}$ Adjunct Professor, UNINOVE.

${ }^{5}$ Assistant Professor of Dental Radiology at FOSJC-UNESP.

${ }^{6}$ Doctorate Student of the Program of Oral Biopathology at FOSJC-UNESP

${ }^{7}$ Assistant Professor, Dental Radiology at FOSJC-UNESP.

${ }^{8}$ Full Professor, Dental Radiology at FOSJC-UNESP.

» The patient displayed in this article previously approved the use of her facial and intraoral photographs.
How to cite this article: Maschtakow PSL, Tanaka JLO, Rocha JC, Giannasi LC, Moraes MEL, Costa CB, Castilho JCM, Moraes LC. Cephalometric analysis for the diagnosis of sleep apnea: A comparative study between reference values and measurements obtained for Brazilian subjects. Dental Press J Orthod. 2013 May-June;18(3):143-9.

Submitted: November 16, 2009 - Revised and accepted: December 29, 2010

» The authors report no commercial, proprietary or financial interest in the products or companies described in this article.

Contact address: Patrícia Superbi Lemos Maschtakow pat.lems@yahoo.com.br / rocha@fosjc.unesp.br 


\section{INTRODUCTION}

The radiographic cephalometry is an important element for investigation of alterations that occur during craniofacial growth and development. This technique transcended the boundaries of odontology and, today, presents significative importance in other areas, such as Otorhinolaryngology, as an important tool for the evaluation of upper airways (UA) and diagnosis of the obstructive sleep apnea-hypopnea syndrome (OSAHS). ${ }^{25}$

The OSAHS consists in repeated apneic events, resultant from total or partial collapse of the pharynx during sleep. It was identified, predisposing factors such as obesity, alterations on the neuromuscular pattern and skeletal or soft tissue anatomical alterations. ${ }^{24}$ Many authors ${ }^{1,4,7,9,21}$ discussed and validated the lateral cephalometric radiograph for evaluation of the UA. Although it consists in method of diagnosis through two-dimensional image, the lateral cephalometric radiograph provides linear and angular measurements that are essential to locate the spots of obstruction of the pharynx..$^{17,18}$

Simões ${ }^{24}$ evaluated through lateral cephalometric radiographs, the pharyngeal space in north American individuals with normal occlusions belonging to Ann Arbor's sample. This work generated a table with standard values that is widely used as reference in Brazilian radiological and orthodontic clinics. However, studies that validated this analysis were not found for the use in the Brazilian population.

In this context, the objective of this study was to verify if reference values of Sleep Apnea cephalometric analysis relative to North American individuals are similar to the ones of Brazilian individuals with no craniofacial anomalies. The study also aimed to identify craniofacial alterations in OSAHS patients in relation to individuals without clinical characteristics of the disease.

\section{MATERIAL AND METHODS}

The present study was approved by the Ethics Committee in Research of the State University of São Paulo, São José dos Campos, School of Dentistry, under the protocol number 103/2007/2006-PH/CEP.

\section{Sample selection}

In the present study, 55 lateral cephalometric radiographs were used. Twenty-six from individuals with diagnosis of OSAHS confirmed by polysomnographic exam, consisted of 18 males ranging from 20 to 70 years of age, and 8 females from 30 to 57 years of age. The radiographs were obtained at the same center of dental radiology. Polysomnographic exams were also performed in a single clinic specialized in sleep disorders.

Twenty nine radiographs of individuals presenting no symptoms relative to OSAHS were also used, comprising 11 males from 18 to 29 years of age and 18 females from 19 to 35 years of age.

The criteria for inclusion of the cephalometric radiographs of OSAHS patients were: Polysomnographic examination report that corroborated the diagnosis of OSAHS available and performed in specialized clinic according to protocol recommended by the Brazilian Society of Sleep on the I Consensus in Snore and Sleep Apnea, ${ }^{27}$ including the AHI values, body mass index (BMI), total period of sleep and period of sleep in each stage, average heart rate and baseline oxyhemoglobin saturation $\left(\mathrm{SO}_{2}\right)$.

Regarding the control group, the criteria were: Existence of medical report with full information about the systemic conditions of the individuals: Not syndromic, did not snore, did not use medicines to induce sleep (hypnotic or neuroleptic), had not been subjected to orthognathic surgical treatment, upper airways treatment or previous orthodontic treatment, did not have respiratory or neurological problems, were not obese and with harmonious facial profile and Class I skeletal pattern.

It were excluded the radiographs that presented the image of the soft palate in format of inverted $\mathrm{V}$, which, according to McNamara Jr., ${ }^{19}$ indicates that the individual swallowed at the moment of obtaining the image, which can interfere on measurements related to this structure.

\section{Cephalometric analysis}

The cephalometric radiographs were digitized with resolution of 300 dpi through flatbed scanner EPSON Perfection 4990 (Epson America Inc., Long Beach, California,USA) with transparency reader attached and its respective software SilverFast ${ }^{\circledR}$ SE 6. The images were saved in TIFF format (Tagged Image File Format) without compression. The cephalometric analysis were performed by a single evaluator and digitized through the software Radiocef Studio 2.0 (Radiomemory, Belo Horizonte/MG). 
In the present study, for the classification of individuals on the control group regarding the sagittal skeletal pattern, it was used the ANB angle. Only individuals with ANB between $0^{\circ}$ and $4^{\circ}$ were selected.

For evaluation of the UA and related structures, it was used the Sleep Apnea analysis which is in the list of analysis of the software and is based on works by Simões ${ }^{24}$ and Pinto. ${ }^{21}$ This cephalometric analysis is constituted of 28 points forming 14 factors (linear measures), shown in Figure 1.

\section{Statistical analysis}

For evaluation of method error, the measures were obtained twice with 30 days interval. The results of both readings were compared through simple Linear Regression Analysis and Student's $t$ test with level of significance at 5\% $(\alpha=0.05)$.

The mean for every factor obtained on the control group was compared to the standard value of the Sleep Apnea analysis through the test. Posteriorly, to verify differences between the group of OSAHS patients and the control group, it was used the Student's $t$ test with $\alpha=0.05$.

\section{RESULTS}

The mean between the first and the second reading of each measure was used to calculate the ana-

Table 1 - Mean, standard deviation (SD) and p value of the 14 linear measures $(\mathrm{mm})$ on control group and standard for females, after application of $\mathrm{z}$ test.

\begin{tabular}{|cccc}
\hline Factor & $\begin{array}{c}\text { Group control } \\
\text { Mean } \pm \text { SD }\end{array}$ & $\begin{array}{c}\text { Standard Value } \\
\text { Mean } \pm \text { SD }\end{array}$ & p value \\
\hline 1) S-N & $69.70 \pm 3.11$ & $73 \pm 3.0$ & 0.2858 \\
\hline 2) ANS-PNS & $53.20 \pm 2.82$ & $54 \pm 3.0$ & 0.7964 \\
\hline 3) Goc-Me & $73.92 \pm 6.37$ & $74 \pm 5.0$ & 0.9883 \\
\hline 4) AA-PNS & $39.88 \pm 5.42$ & $36 \pm 3.0$ & 0.2335 \\
\hline 5) PPFS-PP1 & $20.09 \pm 3.50$ & $24 \pm 3.5$ & 0.2780 \\
\hline 6) $\mathrm{PP2}-\mathrm{PP2}$ & $13.90 \pm 2.48$ & $14 \pm 2.0$ & 0.9618 \\
\hline 7) PNS-P & $33.02 \pm 4.83$ & $35 \pm 4.5$ & 0.6703 \\
\hline 8) PPFM-PAFM & $17.77 \pm 3.36$ & $21 \pm 3.5$ & 0.3683 \\
\hline 9) B-Go/BI & $11.87 \pm 2.93$ & $13 \pm 2.5$ & 0.6643 \\
\hline 10) C3-H & $34.27 \pm 3.70$ & $36 \pm 3.0$ & 0.5808 \\
\hline 11) PM-H & $20.51 \pm 15.32$ & $15 \pm 3.0$ & 0.2398 \\
\hline 12) BI-PI & $69.87 \pm 6.14$ & $72.5 \pm 3.0$ & 0.4308 \\
\hline 13) DI-PI/BI & $22.38 \pm 3.76$ & $24 \pm 3.0$ & 0.6049 \\
\hline 14) C3'-H' & $11.74 \pm 2.85$ & $13.5 \pm 2.0$ & 0.4049 \\
\hline$\times$ Signicant & $5 \% .0$ & & \\
\hline
\end{tabular}

* Significant level: $5 \%$. lyzed factors. The results of $z$ test, used for comparison of means of the control group and of standard values of Sleep Apnea analysis, ${ }^{24}$ are represented on Table 1 and Figure 2 for females and on Table 2 and Figure 3 for males.

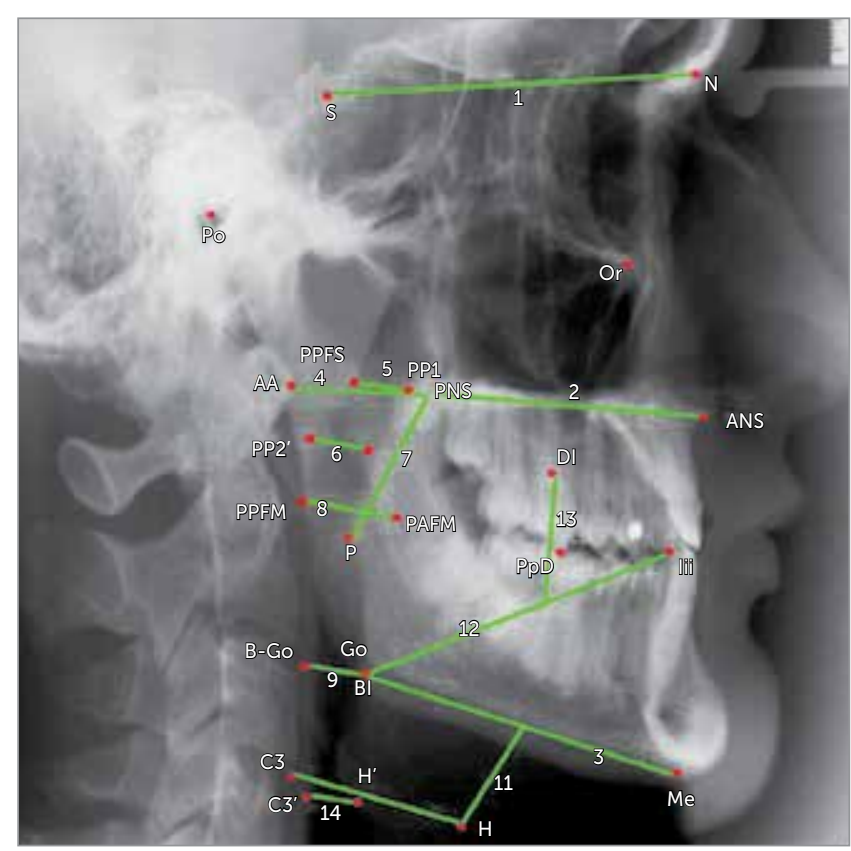

Figure 1 - Representation of points and factors evaluated on Sleep Apnea cephalometric analysis.

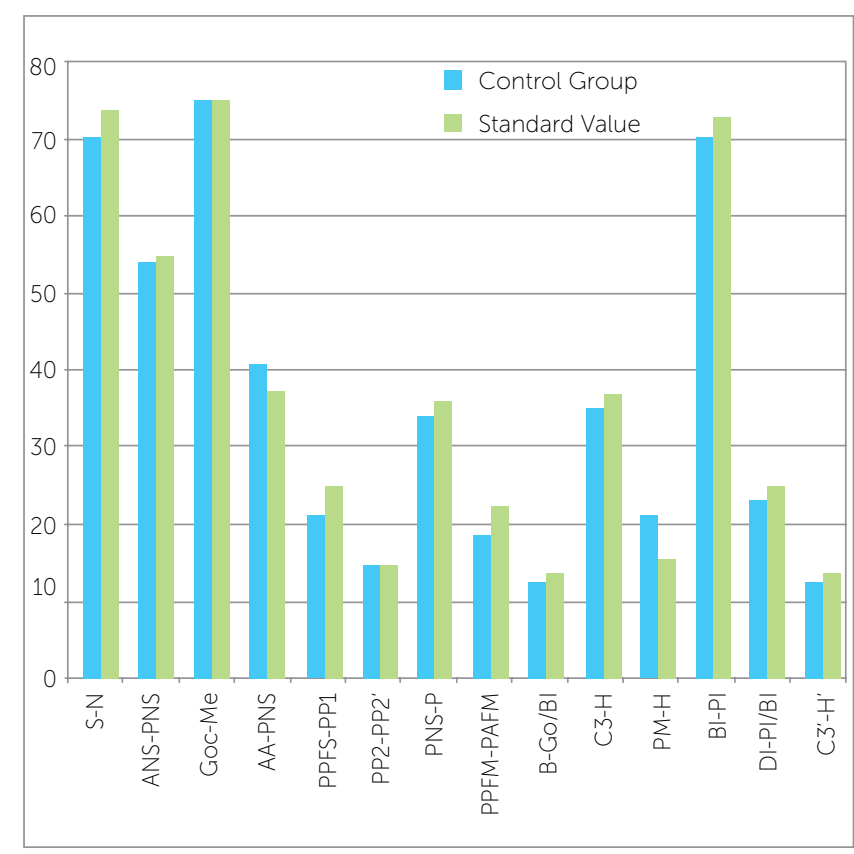

Figure 2 - Graphic of comparison between the factors values, in millimeters, of the control group and standard values in female individuals. 
Table 2 - Mean, standard deviation and $p$ value of the 14 linear measures $(\mathrm{mm})$ on the control group and standard values for male individuals after application of z test.

\begin{tabular}{|c|c|c|c|}
\hline Factor & $\begin{array}{c}\text { Control Group } \\
\text { Mean } \pm \text { S.D. }\end{array}$ & $\begin{array}{c}\text { Standard values } \\
\text { Mean } \pm \text { S.D. }\end{array}$ & p value \\
\hline 1) $\mathrm{S}-\mathrm{N}$ & $76.10 \pm 4.34$ & $80 \pm 2.00$ & 0.1031 \\
\hline 2) ANS-PNS & $60.02 \pm 4.97$ & $62.5 \pm 4.00$ & 0.5625 \\
\hline 3) Goc-Me & $79.26 \pm 4.12$ & $84.5 \pm 5.00$ & 0.3099 \\
\hline 4) AA-PNS & $40.83 \pm 2.32$ & $36 \pm 3.50$ & 0.1758 \\
\hline 5) PPFS-PP1 & $19.91 \pm 2.84$ & $26 \pm 4.00$ & 0.1367 \\
\hline 6) PP2-PP2' & $14.11 \pm 2.04$ & $12 \pm 3.00$ & 0.4894 \\
\hline 7) PNS-P & $34.68 \pm 3.75$ & $34 \pm 5.00$ & 0.8944 \\
\hline 8) PPFM-PAFM & $19.45 \pm 2.41$ & $22 \pm 4.50$ & 0.5761 \\
\hline 9) $\mathrm{B}-\mathrm{Go} / \mathrm{Bl}$ & $14.45 \pm 3.57$ & $15.5 \pm 3.50$ & 0.7749 \\
\hline 10) $\mathrm{C} 3-\mathrm{H}$ & $40.81 \pm 4.29$ & $41 \pm 3.50$ & 0.9614 \\
\hline 11) $\mathrm{PM}-\mathrm{H}$ & $19.79 \pm 4.80$ & $19 \pm 6.00$ & 0.8969 \\
\hline 12) BI-PI & $73.39 \pm 4.88$ & $79 \pm 5.00$ & 0.2819 \\
\hline 13) DI-PI/BI & $24.38 \pm 3.56$ & $29.5 \pm 3.00$ & 0.1084 \\
\hline 14) $\mathrm{C}^{\prime}-\mathrm{H}^{\prime}$ & $16.77 \pm 5.37$ & $17.5 \pm 4.00$ & 0.8617 \\
\hline
\end{tabular}

* Significance level: $5 \%$.

Table 3 - Mean, standard deviation and $p$ value of linear measures in males on the control group and on the OSAHS group after application of Student's $t$ test.

\begin{tabular}{|c|c|c|c|}
\hline Factor & $\begin{array}{c}\text { OSAHS }(n=18) \\
\text { Mean } \pm \text { S.D. }\end{array}$ & $\begin{array}{c}\text { Control }(n=11) \\
\text { Mean } \pm \text { S.D. }\end{array}$ & $p$ value \\
\hline 1) $\mathrm{S}-\mathrm{N}$ & $74.8 \pm 3.3$ & $76.1 \pm 4.3$ & 0.3734 \\
\hline 2) ANS-PNS & $56.9 \pm 5.1$ & $60 \pm 5$ & 0.3734 \\
\hline 3) Goc-Me & $71.1 \pm 3.2$ & $79.3 \pm 4.1$ & 0.3734 \\
\hline 4) AA-PNS & $37.3 \pm 4.1$ & $40.8 \pm 2.3$ & 0.0431 \\
\hline 5) PPFS-PP1 & $14.4 \pm 3.5$ & $19.9 \pm 2.9$ & $0.0000 *$ \\
\hline 6) PP2-PP2' & $7.5 \pm 2.5$ & $14.1 \pm 2.1$ & $0.0000^{*}$ \\
\hline 7) PNS-P & $43.3 \pm 4.5$ & $34.7 \pm 3.8$ & $0.0000 *$ \\
\hline 8) PPFM-PAFM & $15.1 \pm 2.8$ & $19.5 \pm 2.4$ & 0.0000 * \\
\hline 9) $\mathrm{B}-\mathrm{Go} / \mathrm{Bl}$ & $12.1 \pm 3.2$ & $14.5 \pm 3.6$ & 0.0796 \\
\hline 10) $\mathrm{C} 3-\mathrm{H}$ & $43.4 \pm 5.1$ & $40.8 \pm 4.3$ & 0.1545 \\
\hline 11) $\mathrm{PM}-\mathrm{H}$ & $26 \pm 6.5$ & $19.8 \pm 4.8$ & 0.0223 \\
\hline 12) BI-PI & $73.9 \pm 4.9$ & $73.4 \pm 4.9$ & 0.8921 \\
\hline 13) $\mathrm{DI}-\mathrm{Pl} / \mathrm{B} \mid$ & $24 \pm 2.7$ & $24.4 \pm 4.2$ & 0.9500 \\
\hline 14) $\mathrm{C} 3^{\prime}-\mathrm{H}^{\prime}$ & $6.1 \pm 2$ & $16.8 \pm 5.4$ & 0.0000 * \\
\hline
\end{tabular}

* Significance level: $5 \%$

The $\mathrm{p}$ values of comparisons and results of Student's $t$ test for studied groups are represented on Tables 3 and 4.

\section{DISCUSSION}

Through the results of the present study it was observed that, despite the evident physical differences

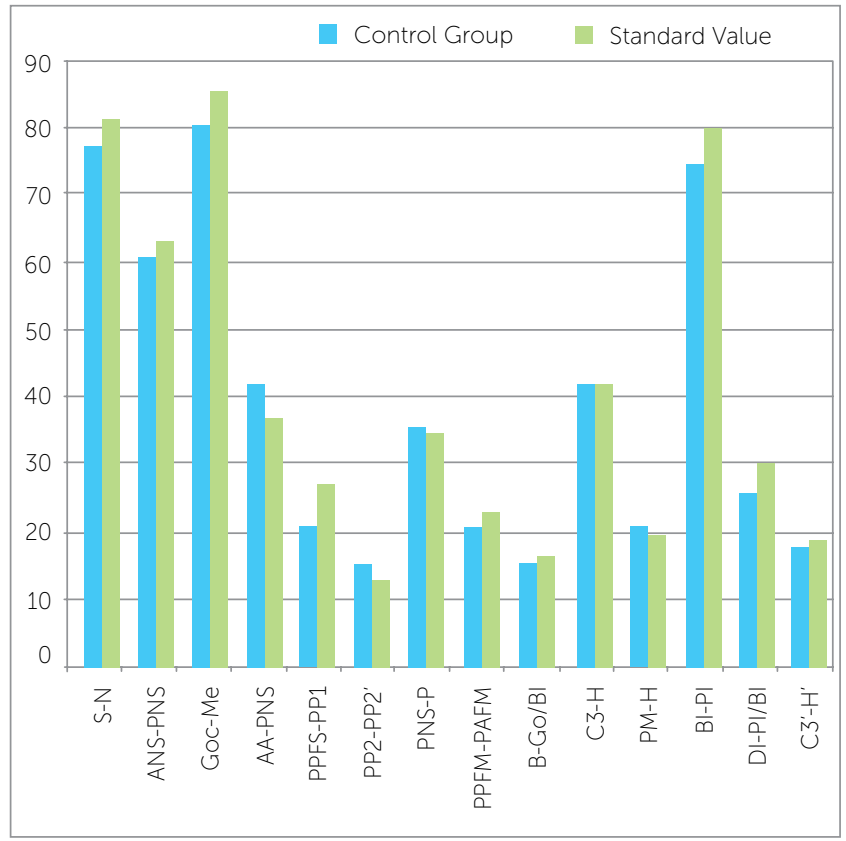

Figure 3 - Graphic of comparison between the factors values, in millimeters, of the control group and standard values in male individuals.

Table 4 - Graphic of comparison between the factors values, in millimeters, of the control group and of the standard values in female individuals.

\begin{tabular}{|c|c|c|c|}
\hline Factor & $\begin{array}{l}\text { OSAHS }(n=8) \\
\text { Mean } \pm \text { S.D. }\end{array}$ & $\begin{array}{c}\text { Control }(n=18) \\
\text { Mean } \pm \text { S.D. }\end{array}$ & $p$ value \\
\hline 1) $\mathrm{S}-\mathrm{N}$ & $68.4 \pm 3.93$ & $69.7 \pm 3.12$ & $0.0021^{*}$ \\
\hline 2) ANS-PNS & $48.8 \pm 4.64$ & $53.21 \pm 2.83$ & 0.0021 * \\
\hline 3) Goc-Me & $68.68 \pm 6.96$ & $73.92 \pm 6.38$ & 0.1869 \\
\hline 4) AA-PNS & $37.25 \pm 6.9$ & $39.89 \pm 4.41$ & 0.5570 \\
\hline 5) PPFS-PP1 & $16.75 \pm 3.78$ & $20.1 \pm 3.51$ & 0.1222 \\
\hline 6) PP2-PP2' & $6.67 \pm 2.51$ & $13.9 \pm 2.48$ & 0.0000 * \\
\hline 7) PNS-P & $41.14 \pm 3.14$ & $33.02 \pm 4.84$ & $0.0003^{*}$ \\
\hline 8) PPFM-PAFM & $12.01 \pm 2.74$ & $17.77 \pm 3.36$ & $0.0005^{*}$ \\
\hline 9) $\mathrm{B}-\mathrm{Go} / \mathrm{Bl}$ & $7.12 \pm 1.57$ & $11.87 \pm 2.94$ & $0.0003^{*}$ \\
\hline 10) $\mathrm{C} 3-\mathrm{H}$ & $41.68 \pm 7.09$ & $34.27 \pm 3.71$ & $0.0005^{*}$ \\
\hline 11) $\mathrm{PM}-\mathrm{H}$ & $23.88 \pm 7.26$ & $20.52 \pm 15.32$ & 0.6133 \\
\hline 12) $\mathrm{BI}-\mathrm{PI}$ & $67.76 \pm 6.21$ & $69.88 \pm 6.15$ & 0.5514 \\
\hline 13) $\mathrm{DI}-\mathrm{Pl} / \mathrm{BI}$ & $19.98 \pm 3.03$ & $22.38 \pm 3.76$ & 0.0000 * \\
\hline 14) $\mathrm{C}^{\prime}-\mathrm{H}^{\prime}$ & $6.08 \pm 2.35$ & $11.74 \pm 2.86$ & $0.0000 *$ \\
\hline
\end{tabular}

* Significance level: $5 \%$

between Brazilian and north American individuals, there was no significative difference on the cephalometric dimensions relative to UA among the individuals of these two nationalities, indicating that there is possibility of using the table of standard values for OSAHS on the evaluation of Brazilian individuals. 
Today, the diagnosis and treatment of OSAHS depend on a multidisciplinary team of health professionals. The dentist, specially the orthodontist, maxillary functional orthopedist and oral and maxillofacial surgeon have fundamental role on the diagnosis of obstruction of UA through radiographs that are part of their work routine. Besides, they participate actively on the treatment of apneic individuals through intraoral appliances ${ }^{11,12,22}$ or orthognathic surgeries.

Several methods of diagnosis by image can be used in order to evaluate the dimensions of UA, however in this study, it was chosen the lateral cephalometric radiograph because this exam is considered the most accessible and widely requested method according to other authors. ${ }^{1,4,17,18}$

The choice for the cephalometric analysis used in this study was due to its large use in radiological and orthodontic clinics and for it embraces measures in all regions susceptible to obstruction.

It was considered important to verify if reference values for the craniofacial measures based in studies with American individuals can be used for Brazilian individuals since in a study comparing OSAHS patients from two distinct ethnicities, Cakirer et $\mathrm{al}^{6}$ found significant differences on the craniofacial characteristics associated to UA between these groups.

The narrowing of the nasopharynx observed in OSAHS male patients (Table 3) was a finding similar to presented by other authors. ${ }^{1,4,17,21,23}$ According to some studies, ${ }^{5,19,21}$ the upper pharyngeal space is one of the regions most susceptible to collapse due to frequent hypertrophy of the pharyngeal tonsils. In the present study, the tonsils were not separately evaluated, however, it was considered the dimensions of the soft tissue on the nasopharynx by marking the posterior point where there was greater obstruction of the airway according to McNamara Jr. ${ }^{19}$

King ${ }^{15}$ mentioned that the forward and downward growth of the face is affected by the anterior growth of the cranial base and posterior growth of the occipital bone or by the association of both, and this growth will contribute to the increase of the pharynx's diameter. In female OSAHS patients was observed a reduction on the cranial base and on the dimensions in all regions of the pharynx. Some authors ${ }^{3,2,8,26}$ mentioned the decrease of the cranial base as one of the cephalometric findings characteristics of OSAHS.
The hyoid bone was more anteriorly positioned in females on the group of OSAHS subjects and did not present significant difference in males on the present research, similar to the findings by Tsai et al, ${ }^{26}$ who found that this factor is associated to greater severity of OSAHS in females.

It is known that the hyoid bone has no bone articulation and is suspended by a grid of muscles and ligaments. Therefore, its position is largely dependent of muscle ligaments, such as tongue, and it is also influenced by the individual's posture. ${ }^{8}$ This fact explains the importance of evaluating this structure in apneic individuals.

Battagel and L'Estrange ${ }^{4}$ asserted that the greater alterations on dimensions of UA in OSAHS patients occur in the oropharynx, agreeing with Lowe et $\mathrm{al},{ }^{16}$ and were related to the reduction of the median posterior palatal space that, in the present work, was also reduced on the group of OSAHS subjects. This space has close relation to the dimensions of the soft palate which increased length was related to presence of OSAHS in several researches $3,4,10,20,25,26$ and the present study.

The lower airspace is significantly reduced on the group of OSAHS patients agreeing with Lyberg et al. ${ }^{17}$ This obstruction of the hypopharynx is related to the epiglottic region that corresponds to the area of great interest for orthognathic surgeries. ${ }^{13}$

On Figure 4, it can be compared lateral cephalometric radiographs correspondent to group of OSAHS subjects and the control group, in which is observed the most common alterations of UA and related structures found on the group of OSAHS patients in relation to the control group.

The hypothesis that anatomic factors, are involved on the etiology of OSAHS has great support in literature. Therefore, it is important to know the anatomic alterations predominant in apneic individuals so that professionals that work directly with lateral cephalometric radiograph can identify risk factors and refer the patient to specialists and specific exams such as polysomnography, considered the gold standard exam for diagnosis of OSAHS. This will contribute to the early diagnosis of the disease, avoiding the severe sequelae related to it.

\section{CONCLUSIONS}

"Craniofacial measures used as reference on the diagnosis of OSAHS, can be applied to Brazilian individuals. 

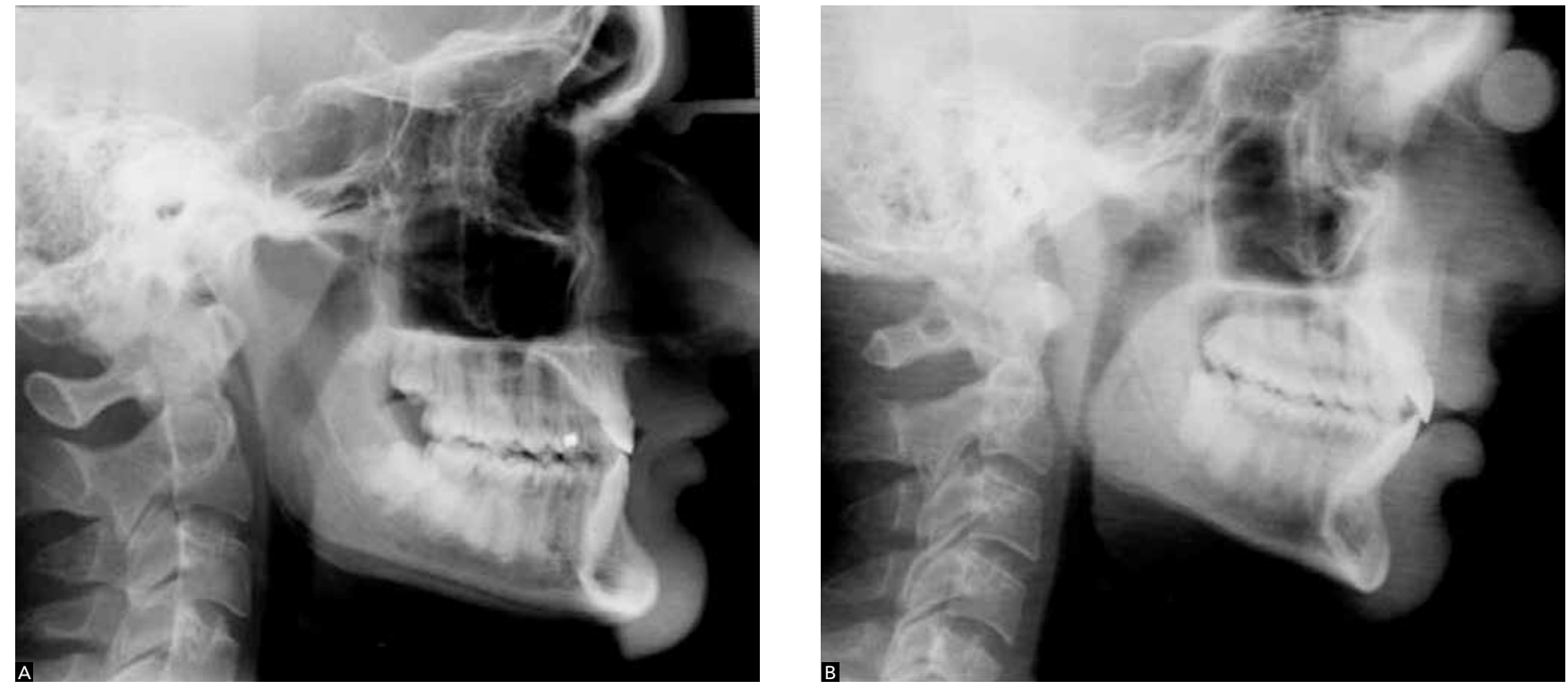

Figure 4 - A) Example of radiographs of control group's individual B) example of radiographs of OSAHS individuals.

» There were significative craniofacial alterations in OSAHS patients when compared to individuals without clinical characteristics of this disease.

"In male apneics it were observed reductions of the upper, mean, inferior and retropalatal air spaces and increase of the soft palate length.

"In female apneics, reduction of the dimensions in all evaluated pharyngeal regions, of anterior cranial base and maxilla length.
1. $\quad$ Andersson L, Brattström V. Cephalometric analysis of permanently snoring patients with and without obstructive sleep apnea syndrome. Int J Oral Maxillofac Surg. 1991;20(3):159-62

2. Bacon WH, Turlot JC, Krieger J, Stierle JL. Cephalometric evaluation of pharyngeal obstructive factors in patients with sleep apneas syndrome. Angle Orthod. 1990;60(2):115-22

3. Bacon WH, Krieger J, Turlot JC, Stierle JL. Craniofacial characteristics in patients with obstructive sleep apneas syndrome. Cleft Palate J. 1988:25(4):374-8.

4. Battagel JM, L'Estrange PR. The cephalometric morphology of patients with obstructive sleep apnoea (OSA). Eur J Orthod. 1996:18(6):557-69.

5. Bell WH. Modern practice in orthognathic and reconstructive surgery. Philadelphia: WB Saunders; 1992.
6. Cakirer B, Hans MG, Graham G, Aylor J, Tishler PV, Redline S. The relationship between craniofacial morphology and obstructive sleep apnea in Whites and in African-Americans. Am J Respir Crit Care Med. 2001;163(4):947-50.

7. Castellucci E, Barbosa M, Knop LAH, Lessa MM, Araujo TM. Avaliação da radiografia cefalométrica lateral como meio de diagnóstico da hipertrofia de adenóide. Rev Dental Press Ortod Ortop Facial. 2009:14(4):83-91.

8. Chaves Júnior CM. Indivíduos com síndrome da apnéia e hipopnéia do sono obstrutiva avaliados pela análise cefalométrica das contra partes de Enlow [tese]. Piracicaba (SP): Universidade Estadual de Campinas; 2000.

9. David FA, Castilho CM. Estudo comparativo entre os traçados manual e computadorizado da análise do espaço aéreo faríngeo em radiografias cefalométricas laterais. Ortodontia. 1999:3(2):288-93. 
10. Faria AC, Ramos MC, Fonseca RG, Paschoal JR. Estudo cefalométrico em indivíduos com distúrbios ventilatórios obstrutivos do sono. J Bras Ortodon Ortop Facial. 2006:63(11):281-8.

11. Giannasi LC, Magini M, Oliveira CS, Oliveira LVF. Treatment of obstructive sleep apnea using an adjustable mandibular repositioning appliance fitted to a total prosthesis in a maxillary edentulous patient. Sleep Breath. 2008;12(1):91-5.

12. Giannasi LC, Mattos LC, Magini M, Costa MS, Oliveira CS, Oliveira LVF. The impact of the Adjustable PM Positioner appliance in the treatment of obstructive sleep apnoea. Arch Med Sci. 2008;4(3):336-41.

13. Gonçales ES. Estudo cefalométrico computadorizado do espaço aéreo faríngeo de indivíduos submetidos à cirurgia ortognática para correção de prognatismo mandibular [tese]. Bauru (SP): Universidade de São Paulo; 2006.

14. Houston WJB. The analysis of errors in orthodontic measurements. Am J Orthod. 1971:83(5):382-90.

15. King EW. A roentgenographic study of pharyngeal growth. Angle Orthod. 1952:22(1):23-6.

16. Lowe AA, Santamaria JD, Fleetham JA, Price C. Facial morphology and obstructive sleep apnea. Am J Orthod Dentofacial Orthop. 1986;90(6):484-91.

17. Lyberg T, Krogstad O, Djupesland G. Cephalometric analysis in patients with obstructive sleep apnoea syndrome. I. Skeletal morphology. J Laryngol Otol. 1989:103(3):287-92.

18. Lyberg T, Krogstad O, Djupesland G. Cephalometric analysis in patients with obstructive sleep apnoea syndrome. II. Soft tissue morphology. J Laryngol Otol. 1989:103(3):293-7.

19. McNamara Jr JA. A method of cephalometric evaluation. Am J Orthod Dentofacial Orthop. 1984;86(6):449-69.
20. Partinen M, Guilleminault C, Quera-Salva MA, Jamieson A. Obstructive Sleep Apnea cephalometric roentgenograms the role of anatomic upper airway abnormalities in the definition of abnormal breathing during sleep. Chest. 1988;93(6):1199-205

21. Pinto AJ. Ronco e apnéia do sono. Rio de Janeiro: Revinter; 2000.

22. Rodrigues AAAAS, Rodrigues RND. Aparelho intrabucal para o tratamento dos transtornos respiratórios do sono: qual a sua influência nos parâmetros cardiológicos do paciente? Rev Dental Press Ortod Ortop Facial. 2008;13(3):20-2.

23. Silva ELC, Campos PSF, Fontes FHO, Macedo Sobrinho JB, Panella J. Accuracy of cephalometric pharyngeal analysis for diagnosis of obstructive sleep apnea syndrome (OSA). Rev Ci Med Biol. 2005:4(2):118-24.

24. Simões DO. Cefalometria em apnéia do sono. In: Colombini NEP. Cirurgia da face: Interpretação funcional e estética. Sindrome da apnéia obstrutiva do sono: enfoque maxilofacial e otorrinolaringológico. Rio de Janeiro: Revinter; 2002. p. 572-96

25. Strauss RA, Burgoyne CC. Diagnostic imaging and sleep medicine. Dent Clin North Am. 2008;52(4):891-915

26. Tangugsorn V, Krogstad O, Espeland L, Lyberg T. Obstructive sleep apnoea: multiple comparisons of cephalometric variables of obese and non-obese patients. J Craniomaxillofac Surg. 2000;28(4):204-12.

27. Tsai HH, Ho CY, Lee PL, Tan CT. Sex differences in anthropometric and cephalometric characteristics in the severity of obstructive sleep apnea syndrome. Am J Orthod Dentofacial Orthop. 2009;135(2):155-64.

28. Tufik S, Sampaio PL, Weckx LLM, et al. Consenso em ronco e apnéia do sono. São Paulo: Sociedade Brasileira de Sono; Rinologia e Otorrinolaringologia; 2000 